\title{
Speaking Their Sex: A Study of Gender and Linguistic Space in an ESL Classroom
}

\section{Allyson Julé}

This study is an exploration of the amount of talk (also referred to as "linguistic space," Mahony, 1985) used by girls as opposed to boys in a grade 2 ESL classroom located in the Lower Mainland of British Columbia. The focus was on the amount of language used by the girls in teacher-led classroom lessons. Data were collected through videotaped observations, which were then transcribed, measured by counting words, and analyzed for conversational opportunities. The findings revealed that being a girl may have affected participation in the classroom lessons, and by extension affected language-learning opportunities. The particular lack of linguistic space in the girls' experience suggests that the girls in this classroom may be limited in language use. Their silence appeared partly influenced by the teacher's response to their comments. The article concludes with a discussion of gender as a significant linguistic variable in an ESL experience.

Cette recherche consiste en une évaluation quantitative du dialogue (aussi appelée "espace linguistique", Mahony, 1985) qu'emploient les filles par rapport aux garçons dans une classe de deuxième année en ALS dans la vallée du bas Fraser de la Colombie-Britannique. Plus précisément, l'auteure a étudié la "quantité de discours" qu'employaient les filles en salle de classe pendant que l'enseignant donnait les leçons. La cueillette de données s'est faite par le biais d'enregistrements vidéo qui ont ensuite été transcrits, mesurés par le dénombrement des mots, et analysés pour en déceler les occasions conversationnelles. Les résultats indiquent que le fait d'être une fille a pu influencer la participation pendant les leçons et donc, par extension, la participation aux activités liées à l'apprentissage de la langue. Le manque d'espace linguistique qui caractérise l'expérience des filles laisse supposer que les filles dans cette salle de classe sont limitées dans leur usage de la langue. Leur silence semblait être en partie influencée par la réaction de l'enseignant à leurs commentaires. L'article se termine par une discussion des rapports sociaux entre les sexes comme variable linguistique significative dans l'expérience des étudiants en ALS.

\section{Introduction}

In the field of second-language acquisition, much attention has been paid to which variables (such as age, race, social class, ethnicity, or gender among a host of others) have influence on language use. The intent of this study is to examine gender at an intersection with ethnicity by exploring it in an ESL 
experience. The past 25 years or so have presented educators with a wealth of research on what happens to girls in schools, although female students may not actually be benefiting from this research (Sunderland, 1994, 1995, 1998; Vandrick, 1999a, 1999b; Willett, 1996; Yepez, 1994). There is a compelling need, then, to bring feminist pedagogical perspectives to ESL research. In this study, the amount of talk in an ESL classroom is measured and discussed, examining specifically the lack of linguistic space for girls in this context. The concept of linguistic space was first used by Mahony (1985) when referring to conversational participation in a British classroom. This study borrows the term as a way to explore the use of language in an ESL classroom.

If we consider the amount of talk that children encounter on a daily basis and how talk may be at times antagonistic to, or encouraging of, their participation in classroom discourse, then an analysis of classroom talk is always relevant to ESL research. This particular ESL classroom is located in one of the few independent schools operating in British Columbia that enroll children of a particular cultural and linguistic heritage, in this case, Punjabi Sikh. Rigorous educational research that seeks to explore and analyze the actual experiences in such ESL classrooms contributes to a needed understanding on the part of ESL educators concerning what language experiences are occurring and how ESL language lessons "do gender" (Thorne, 1993; West \& Zimmerman, 1987).

\section{Background}

Much work, largely anthropological and/or linguistic, has investigated speech communities by identifying certain linguistic forms as "restricted" or "adjusted" in use based on gender (Cameron, 1995; Davies, 1999; Delamont, 1990; Gupta \& Umar, 1994; Oxford, 1993). Western feminists from a variety of disciplines have proposed that a particular form of female language use exists, although others disagree with, or criticize, such a view, seeing it as possibly destructive or redundant in the larger gender debate on differences (Cameron, 1995). Much attention has been paid to gender and language in conversational practice or patterns, in discourse among same-sex groups, and in public mixed talk, as well as in theoretical discussions of how power and dominance are made manifest in language (see Coates, 1998, for a fuller exploration of such debate).

More recently, concerns in education have involved masculinity and achievement. The "underachievement of boys" (Connell, 1996; Davies, 1999) has been seen by some as a result of girls' achievement levels overtaking those of boys in some subjects. As a result, there has been less recent focus on girls in classrooms. It appears it was researchers working predominantly in the 1970s and 1980s who investigated the disadvantage of girls in classrooms (Clarricoates, 1978; Mahony, 1985; Spender \& Sarah, 1980). Such work articu- 
lated the marginalization of girls in education, and although such work was convincing, it has become perhaps less engaging as the current concern for the underachievement of boys gained momentum in the 1990s (Connell, 1996; Yates, 1997). Davies (1999) discusses this shift in educational research as a response to a "moral panic" in Western society over white middle-class boys becoming the new marginalized, the new "deprived" (p. 39). Davies suggests that it may well be boys and not girls who are "losing out" largely because of competitive male speech patterns as opposed to more collaborative patterns often viewed as, and seen in, female language patterns (Coates, 1998).

In many ways it is from a growing concern for boys' underachievement in mainstream education that this ESL study on gender emerges. If the feminist educational research of the 1970s and 1980s has done its job in bringing girls out from the margins of academic life, then why are the girls in this classroom speaking for less than $2 \%$ of the time? If feminism has perhaps affected education to the point of overemphasizing female participation at the expense of boys' achievement, then why is there such a discrepancy between male and female participation in this ESL classroom?

Much feminist research has suggested that girls may not receive equal attention from teachers or adequate opportunities to speak in classrooms (including Gilligan, 1992; Orenstein, 1994; Sadker \& Sadker, 1994). Mahony (1985) saw gender in classrooms as an indication of teacher attitudes, that is, boys are often seen as the privileged learners, and this is evidenced in how they monopolize teacher attention. In Mahony's study, for every two boys to ask questions, there was one girl; three boys to one girl received praise and encouragement. She referred to such linguistic significance as use of linguistic space, and compared it with the gendered use of physical space in classrooms (boys moving around the room with more regularity and ease). Such possibilities need to be explored in ESL settings. Willett (1996) asks, "Why has the TESOL profession taken so long to examine gender? Whose stories are being told in our research?" (p. 344). Vandrick (1996b) adds to this, "Now we need to find out which [feminist] research results apply to ESL students and classrooms" (p. 16). Speaking to the gap in educational research connecting gender and ESL, the intention of this study is to turn some attention to the issue of gender in a Canadian ESL classroom.

Female students across ethnic lines may be receiving messages that "girls must be more refined," and it may be reasonable to suggest that their often silent participation in classroom lessons is a deliberate response to being instructed into such silence (Stanworth, 1981). One of the more disturbing pieces of classroom research is found in the early work of Clarricoates (1978) in which she concluded, quite starkly, that "teachers like teaching boys." Spender (1980) explained further this type of sentiment on the part of teachers: 
When boys ask the right questions, it shows that they are bright; when girls ask them it shows they know what is expected of them ... When classroom management is the over-riding concern of teachers-and there are many who contend that control is the major educational objective in the classroom-the passivity of girls can be seen as a desirable feature. (p. 152)

Ultimately, then, there can be implicit messages in classrooms that female students do not count as significantly as the male students. Because much research has indicated that boys talk more, interrupt more, and exert more control over talk (Coates, 1996; Sadker \& Sadker, 1994; Sheldon, 1997; Stanworth, 1981; Zimmerman \& West, 1975), by deduction, then, girls say less. Because schools and classrooms are pervasive language environments, and because students are dealing with language most of the time, the classroom dialogue is in many ways the entire educational process. And, with the growth in importance of student-centered learning, classroom talk is increasingly seen as central to the learning process. If girls are not gaining equal access to talk (or even remotely claiming balanced opportunities), this must make an impact on their learning.

For Swann and Stubbs (1992), who see Kramsch's (1993) "communicative competence" as central to the ESL classroom, language is a form of social practice: how language is used in classrooms reflects the significance of the participants. If we want to know how ESL girls are coping in, or benefiting from, their classrooms, it seems obvious that we must observe the amount of talk as an important element in language acquisition.

The inequality of talk in classrooms, something found in many feminist pedagogical and linguistic studies, is not an incidental feature of female speech (that "girls are like that"), but is often one result of complex social processes that have accelerated the imbalance. Such inequalities in language use may appear evident in ESL classrooms as well. In the rapid exchange in classroom discussions of teacher-student talk, it is often the first student to respond (raising a hand or making eye contact) who receives the attention of the class, and this student is usually male (Swann \& Stubbs, 1992). By engaging in such forms of discourse interaction, teachers are not only distancing those who may be less competitive, but are at the same time giving those who already excel in claiming the floor yet further opportunities to speak.

This particular Punjabi Sikh ESL classroom presents an important case for gender in ESL research concerning possibilities for language acquisition, in part because of the Punjabi Sikh community's growing population in British Columbia and the increasing numbers of Punjabi Sikh students in British Columbia's schools (Statistics Canada, 1999). Because all the students in this classroom are of the same ethnic heritage, attention can be uniquely paid to gender as a linguistic variable without engaging in ethnic and cultural generalities about girls. The possibility that gender may limit or silence some 
of these students in certain educational experiences contributes to the discussion of results. In this regard, this study hopes to interrupt the positioning of "being a girl" in ESL settings through a specific examination of linguistic space.

\section{The Study}

\section{Research Question}

This study offers some response to the question: How are some ESL girls experiencing their language classroom? The central aim of the study was to examine gendered patterns surrounding the use of linguistic space in female ESL learners' experience. It was also the intention to examine the nature of classroom talk nested at the intersection of gender and ethnicity, as they operate simultaneously in a single context, where the language of instruction was English.

\section{Context and Methodology}

The focus here is on the experiences in one grade 2 ESL classroom during more than 40 hours of classroom observation. Videotaped data were collected on a weekly basis beginning in September 1998 and concluding in June 1999. The class had 20 students: 11 boys, nine girls. The teacher was not of Punjabi ancestry. She was a Canadian-trained teacher of Anglo-Saxon heritage with nine years of ESL teaching experience at this private Punjabi Sikh school.

The data were transcribed and analyzed to reveal the amount of linguistic space used by the participants in this classroom. The morning literacy lessons that began each day in this classroom were isolated in a stratified random sample (i.e., similar teacher-led class discussions were selected from the fuller transcriptions, and then monthly samples were chosen from these samples to provide glimpses of the full year). Ten segments resulted, and the words of the teacher and the students were counted and measured for percentages of the use of linguistic space. In student talk, both the amount of boy talk and girl talk were separated and measured by counting words to further reveal the linguistic participation of the girls in classroom events. Following from the word-count analysis, the types of speech acts were examined and documented to gain a sense of the linguistic content and context. Such methods were used in keeping with Cameron's (2001) view of "ethnography of speaking" as "an approach to talk" that focuses on "situations and events," and the speech acts in them, that emerge from a particular community or group (p. 48). 
Table 1

Linguistic Space (Breakdown by Word Count)

$\begin{array}{ll}\text { T: Teacher } & \text { S: All students } \\ \text { B. Boys } & \text { G: Girls }\end{array}$

Count per speaker

Separate turns

at speaking

Segment $1-637$ words total

T: $\quad 497$ words $\quad 78 \%$

S: 140 words $\quad 22 \%$

B: $\quad 125$ words $\quad 19.6 \%$

G: 15 words $\quad 2.4 \%$

7.8 word average

16

5.0 word average

3

Segment 2-838 words total

$\mathrm{T}: \quad 792$ words $\quad 95 \%$

S: $\quad 46$ words $\quad 5 \%$

B: 46 words $\quad 5 \%$

G: -

Segment 3-745 words total

T: $\quad 691$ words $\quad 93 \%$

S: $\quad 54$ words $\quad 7 \%$

B: $\quad 40$ words $\quad 5 \%$

G: 14 words $\quad 2 \%$

4 word average

10

4.7 word average $\quad 3$

Segment 4-600 words total

T: $\quad 530$ words $\quad 88 \%$

S: $\quad 70$ words $\quad 12 \%$

B: $\quad 67$ words $\quad 11 \%$

G: 4 words $\quad 1 \%$

3.9 word average

17

4 word average

7

Segment 5-662 words total

T: $\quad 516$ words

$78 \%$

S: 146 words $\quad 22 \%$

B: 124 words $\quad 19 \%$

G: 22 words $\quad 3 \%$

9.5 word average $\quad 13$

Segment 6-778 words total

T: $\quad 756$ words

S: $\quad 22$ words

$97 \%$

$3 \%$

$3 \%$

2.2 word average

10

G:

Segment $7-460$ words total

$\mathrm{T}$ : $\quad 389$ words

$85 \%$

S: $\quad 71$ words

$15 \%$

B: $\quad 62$ words

$13 \%$

2.4 word average

26

G: $\quad 9$ words

$2 \%$

1.5 word average

6 
Table 1 (continued)

Count per speaker

Separate turns

at speaking

Segment 8-834 words total

$\mathrm{T:} \quad 737$ words

$88 \%$

S: $\quad 97$ words

$11 \%$

$B: \quad 87$ words

$10 \%$

G: $\quad 10$ words

$1 \%$

5 word average

10 word average

1

Segment 9-461 words total

$\mathrm{T}: \quad 452$ words

$98 \%$

S: $\quad 9$ words

$2 \%$

B: $\quad 7$ words

$1.5 \%$

1.16 word average

6

G: $\quad 2$ words

$0.5 \%$

1 word average

2

Segment $10-559$ words total

$\mathrm{T}: \quad 526$ words

$94 \%$

S: $\quad 33$ words

$6 \%$

B: $\quad 28$ words

$5 \%$

G: $\quad 5$ words

$1 \%$

4 word average

7

2.5 word average

2

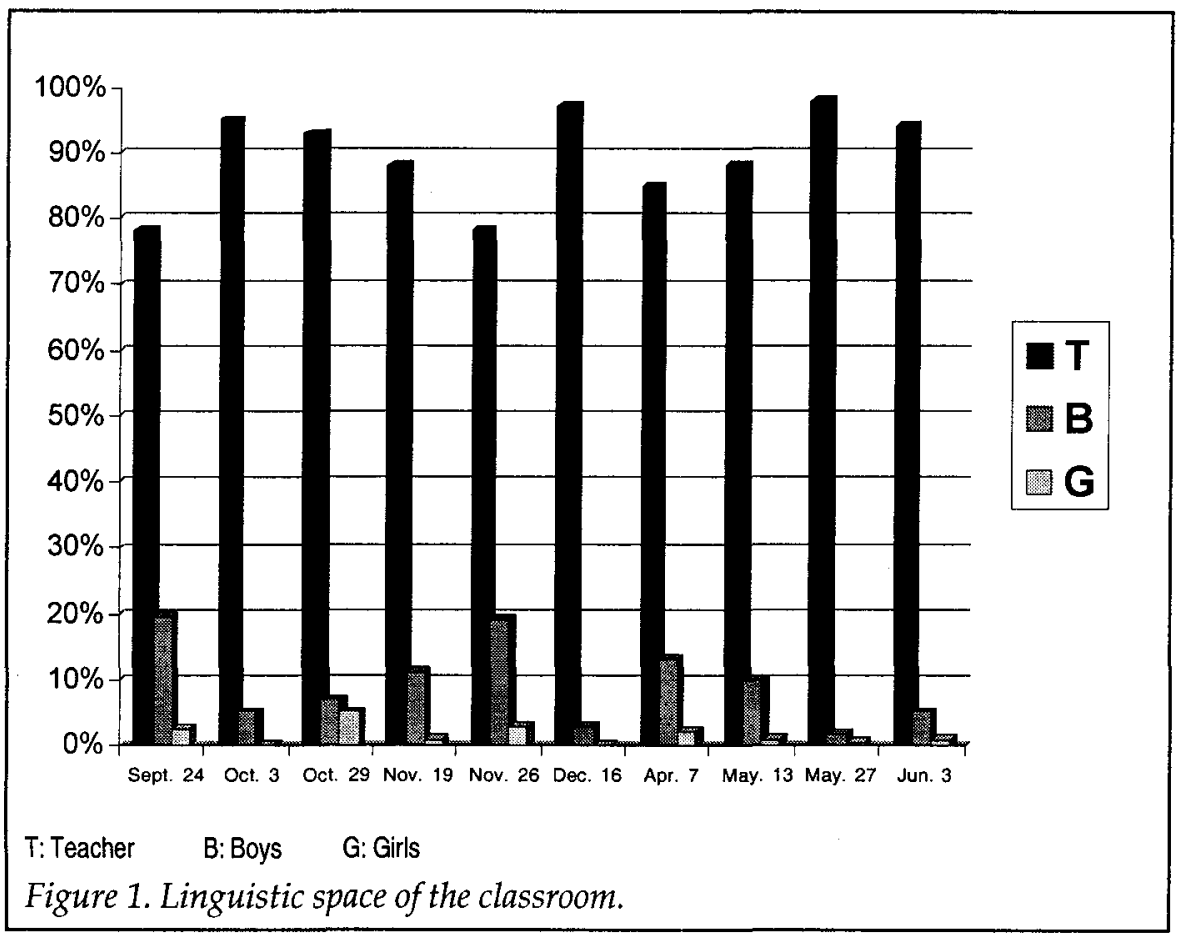




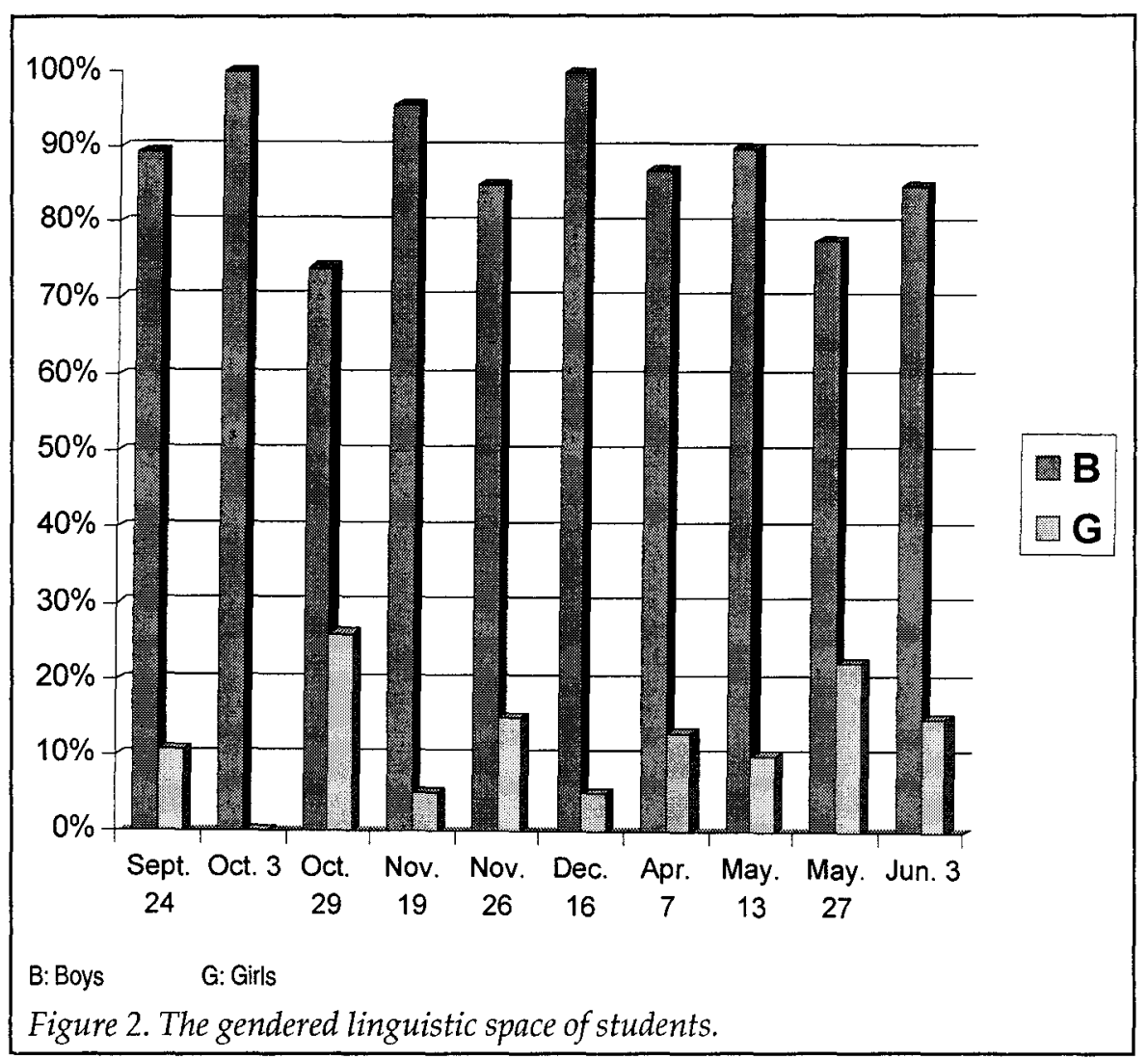

\section{Findings}

\section{The Linguistic Space}

The amount of time the teacher spoke stood out immediately when viewing the transcripts. Such teacher-dominated discourse is not surprising as the segments were pulled from the teacher-led classroom lessons. In each of the 10 segments, the teacher used on average $80 \%$ of the linguistic space; the students divided the remaining $20 \%$ between them, with the boys accessing most of it. A breakdown of word production is provided in Table 1. The results of these measurements are further demonstrated in chart form (Figure 1).

When the teacher's talk is eliminated from the analysis of linguistic space, it becomes clearer how gender determined the use of linguistic space in this classroom. Figure 2 presents the same data as above, but only the students' participation is graphed.

As evidenced in the segments of classroom lesson times and demonstrated in the two figures that present the word counts, several findings emerge. 
On average, the teacher spoke for $89.4 \%$ of the time (ranging from $78 \%$ to $97 \%$ ). Her students were left on average with $10.5 \%$ of the remaining time (ranging from $2-22 \%$ ). Of this, the boys spoke for most of the time $(88.3 \%$ ). The girls spoke for only $11.7 \%$ of the time. The girls spoke for a mere $1.29 \%$ of the total classroom discussion time (ranging from $0 \%$ to only $3 \%$ ). The boys, then, spoke nine times as much: a 9:1 ratio of linguistic space in favor of the boys.

When particular students' contributions are examined, we can see that a maximum average of 9.5 words were spoken at one time, and this can be attributed to the boys (Table 1). Girls reached a high of only an average length of a 5.5 word response, although in one segment one girl said 10 words at one time. Seen this way, the linguistic production on the part of all the children is minimal, but the girls in particular have little to contribute to the classroom discussions. The boys spoke more often than the girls and said more when they did.

\section{Classroom Talk}

In the light of these findings, it may be reasonable to explore the speech acts to understand whether and how gender appears to be a factor in the interactions between the teacher and the students. Of significance, then, are the type of contributions offered in each of the classroom discussion segments. The speech acts are accounted for in Tables 2 and 3. Table 2 documents the teacher's speech acts; Table 3 documents the students' speech acts. Note that the figures represent actual occurrences rather than percentages.

Table 2

Teachers' Speech Acts

\begin{tabular}{lcccc}
\hline Speech act & To the class & To a boy & To a girl & Total \\
\hline Question & 67 & 11 & 1 & 79 \\
Repetition of a student's comment & 10 & 44 & 5 & 59 \\
Explanation & 32 & 1 & & 33 \\
Negative response to a question & 7 & 20 & 4 & 31 \\
Instruction/guidance & 28 & & & 28 \\
Positive response & 5 & 14 & 5 & 24 \\
Direct order & 1 & 10 & 2 & 13 \\
Ignoring student's comment & & 10 & 2 & 12 \\
Criticism & & 8 & 2 & 10 \\
Praise/reinforcement & 1 & 3 & & 4 \\
General comment & 3 & & & 3 \\
Story-telling & 2 & & & 2 \\
\hline
\end{tabular}


Table 3

Students' Speech Acts

\begin{tabular}{lcccc}
\hline Speech act & Group & Boys & Girls & Total \\
\hline Response to a question & 15 & 57 & 8 & 80 \\
Uninitiated comment & & 21 & 3 & 24 \\
Question to teacher & & 1 & 1 & 2 \\
Storytelling & 1 & & 1 \\
\hline
\end{tabular}

As evidenced in Table 2, the most often used speech act by the teacher was questioning (79 occurrences). She most often directed her questions to the class as a whole (67 times), then specifically to the boys (11 times), and only once directly to a girl. She often repeated a student's comment as recognition of his or her contribution ( 59 times). But this was most often directed to a boy ( 44 times), and only a few times to a girl ( 5 times), again almost a 9:1 ratio of boys to girls.

The teacher-question-response-evaluation pattern is not a surprise when describing classroom speech acts (Thornborrow, in press). It appears clear in this classroom, however, that the classroom discussion is essentially a conversation between the ESL teacher and the boys in her class: the teacher usually asked questions (79 occurrences), and these were usually answered by boys ( 57 responses). Only 8 responses were offered by girls.

The teacher also commonly used explanation and instruction in her talk, followed closely by negative or positive comments, such as "No" or "That's right!" (negative responses: 31; positive: 24). Of her responses, most were directed to boys ( 24 times) over girls ( 9 times) or 2.5:1. Although negative comments were also directed to boys more often than to girls (5:1), so were the positive comments (3:1). The teacher offered praise 4 times, once to the whole class and 3 times to a boy; she never offered praise to a girl in these video segments. Such a discrepancy is similar to those found in feminist educational research, such as Mahony's (1998) study where 2:1 questions were directed to boys over girls and 3:1 praise was offered to boys over girls. It may be consistent that boys receive more teacher attention than girls receive in similar speech moments.

The students' speech acts in this ESL classroom were usually responses to the teacher's questions, and the boys appear to be the usual and consistent responders. It was the boys who called out (21 such acts in boys to only 3 in girls, 7:1). Only two questions came from the students themselves-one from a boy and one from a girl. Only one speech act revealed a student sharing information independent of teacher prompts, and this was a boy's speech act. 
An examination of the kinds of speech acts attempts to account for the types of things said, further illuminating the linguistic environment in this ESL classroom, in spite of the interpretive aspect to such a tally. Even if another researcher might account for the speech acts differently, he or she would have to acknowledge that girls rarely spoke. The few times girls did speak, they offered only phrasal comments, such as: "He planted appleseeds" or "They call them apple-seeds" (from Classroom Segment 1), whereas the boys' responses were often more substantial, such as: "and she climbed up all the tree, then she didn't say help, then she couldn't help the fire truck came then she came down" (from Classroom Segment 1). Boys not only spoke more often, they made more substantive remarks when they did.

Evident in the data is the minor role the girls played in most of the lesson time in this classroom. This lack of linguistic space supports similar findings of male native speaker domination of classroom talk in earlier work (Coates, 1996; Graddol \& Swann, 1989; Stubbs, 1976). The full-class lessons in this ESL classroom seemed regularly to involve interactions of the teacher and her male students, with the girls generally appearing as observers of the classroom talk, a pattern also noted by such researchers as Mahony (1985), Swann (1992), and Stanworth (1981). In the final analysis of the amount of talk in this classroom, there was a general 9:1, sometimes even 10:1, ratio of boys' compared with girls' use of the linguistic space. The discrepancy can alert ESL teachers to gender as perhaps a major factor in language production, that is, boys may talk more in other ESL classrooms as well.

In this study, the imbalance was consistent throughout the 10 months of observation and in the various segments used for analysis. The disproportion of linguistic space used by the girls in this ESL classroom did not shift as the year progressed; instead, the lack of linguistic space in the girls' experience remained a constant.

\section{Discussion}

The analysis of both the claiming of linguistic space and the particular types of speech acts produced in this ESL classroom (however glossed over in this limited analysis) reveal complex issues related to the amount of talk on the part of the girls. Viewed through Hymes' (1972) influential concept of "communicative competence," it becomes clear that the girls did not have, or did not take, complete freedom in their classroom to demonstrate their "communicative competence," despite a focus on developing fluency in English in their language classroom. Perhaps the girls' silence was a response to the particular ways their teacher engaged in speech acts, or perhaps it was influenced by other variables such as cultural norms or age-related behaviors. Regardless of the many possible explanations for their silence, the girls rarely participated in full-class talk, and they rarely joined in the narra- 
tives of others. Their silence may be viewed as passive, or it may be active resistance to the attention given to the boys.

What may be more disturbing, though, is not just the clear imbalance of boy-girl attention and participation in this classroom, for much of what we have been led to expect from feminist studies of classrooms matches the discrepancy. Rather, the disturbance results from the irony that an ESL classroom is a communicative environment, a language-learning classroom, and yet one group in it is hardly speaking at all. The lack of use of linguistic space among the girls in this ESL classroom may alert ESL educators to the possibility that despite efforts that have gone into exploring gender in classrooms, the ESL classroom may have been forgotten.

Ultimately, the results of this study show that this culturally specific ESL classroom community did not interrupt the power gender played in the classroom experience as seen in Western feminist thought. That some students are girls figured largely into the amount of speech used in this classroom. Such a discovery may implicate ESL teacher training by the suggestion that there may not be adequate emphasis placed on gender as a variable in language classrooms. Being a girl is an important variable that may be a more significant predictor of eventual linguistic attainment than generally acknowledged in ESL teacher training programs.

Of course, generalizations cannot be made based on one example of an ESL classroom; however, this study points to the need for more reflective classroom practice and research concerning ESL and gender. Because gender may be a powerful predictor of language use, this study suggests that various classroom relationships such as that between teacher and student need to be carefully examined. This study brings forward some limited evidence that boys use more linguistic space than girls do, that boys talk more often and for greater periods of time. The student contributions to classroom dialogue can be somewhat explained by examining the teacher's speech acts; that is, the teacher appeared to engage with the contributions made by the boys and seemed to dismiss the contributions made by the girls. Given that classrooms are "sites of struggle" (Walkerdine, 1990, 1997), what may be the struggle of ESL girls is the opportunity to speak at all. The possibility of such a constructed silence needs to be seriously considered by ESL teachers and by future ESL research.

\section{Conclusion}

This study provides fresh evidence of how gender can be an important linguistic variable in an ESL classroom. The particular lens of linguistic space brings gender to the fore of the classroom experience. If debates about gender in the classroom are thought to be a thing of a 1970s past, debates largely settled in other sociological fields, then this study suggests such debates are not over. In fact these debates may be just beginning in the ESL 
field if gender is seen as a possible predictor of ESL learning. The experiences of these young language learners suggest that gendered access to linguistic space is a powerful reality. ESL teachers may be encouraged to give more attention to the length and frequency of speech production of their female students, and to give some attention to the use of linguistic space in their own classrooms.

Learning and language learning happen through talk. It is, therefore, crucial if some students (often boys) have opportunities to talk in classrooms, while other (often girls) claim disproportionate access to the linguistic space of the room. ESL classrooms and ESL teachers can be organized such that gender is recognized as a significant variable in speech production. How this can be carried out is by no means simple because classroom day-to-day conversations are often spontaneous and appear intuitive and natural. To shift the use of linguistic space so as to provide ESL girls with more time to produce language will take more than an awareness on the part of ESL educators: it will take teaching awareness and strategies.

Particularly when girls are involved in class discussions, ESL teachers need to be aware of the possible extra pressures on them as female students. Giving attention to girls who do attempt to speak, as well as to what girls are saying, may go a long way in supporting more classroom interaction from girls. ESL teachers waiting longer for girls to reply or specifically asking girls to participate in conversations may also be helpful. Such specific teacher practices may need to be explicitly taught in TESL training programs.

Finally, it would appear appropriate for ESL teachers to structure talk-related activities to be more inclusive and to prepare girls for classroom discussions before they begin. If ESL girls are quiet, or are kept quiet, this silence may impede their language learning potential. ESL girls may be shy and quiet of their own accord, but the possibility of systematic silencing of girls in ESL classrooms may need further attention by both ESL teachers and ESL researchers. Research is needed in ESL classrooms across cultural groups, across contexts, across grade levels is needed, if we are to address the processes that may be limiting the potential of female students. Who is talking? is a critical question for ESL teachers.

This ESL classroom is just one particular case and is dependent on local understandings. But even the local complexity can implicate other ESL classrooms, each filled with unique and local issues. All ESL classrooms share with this one the variable of gender and its potential to influence speech production. Such recognition of gender as a prime linguistic variable challenges ways of thinking about ESL education as benign or neutral. This study invites further examination of gender construction in ESL classrooms. As the data show, sometimes girls can be seen to be denied linguistic space in classrooms by the practices of language teachers themselves. ESL teachers 
would do well, then, to take measures to ensure that girls claim and use their fair share of linguistic space.

\section{Acknowledgments}

This research was initially funded by the Metropolis (RIIM) Project at Simon Fraser University, Burnaby, British Columbia.

\section{The Author}

Allyson Julé (PhD, University of Surrey Roehampton, London, UK) teaches in the TESL Certificate Program at Trinity Western University, Langley, $\mathrm{BC}$ and at the English Language Institute at the University of British Columbia. Her research interests include gender in ESL, the Punjabi Sikh experience in Canada, ethnography in education, and classroom talk analysis.

\section{References}

Cameron, D. (1995). Rethinking language and gender studies: Some issues for the 1990's. In S. Mills (Ed.), Language and gender: Interdisciplinary studies (pp. 31-44). London: Longman.

Cameron, D. (Ed.). (1998). The feminist critique of language: $A$ reader (2nd ed.). London: Routledge.

Cameron, D. (2001). Working with discourse. London: Sage.

Clarricoates, K. (1978). Dinosaurs in the classroom: An examination of some of the aspects of the hidden curriculum in primary schools. Women's Studies International Quarterly, 1, 353-364.

Coates, J. (1996). Women talk: Conversations between women friends. Cambridge, MA: Blackwell.

Coates, J. (1998). Introduction. In J. Coates (Ed.), Language and gender: A reader (pp. 1-5). Oxford, UK: Blackwell.

Connell, R.W. (1996). Masculinities. Cambridge: Polity Press.

Davies, J. (1999). Expressions of gender: An enquiry into the way gender impacts on the discourse styles of pupils involved in small group talk during GCSE English lessons with particular reference to the under-achievement of boys. Unpublished doctoral thesis, University of Sheffield, UK.

Delamont, S. (1990). Sex roles and the school (2nd ed.). London: Routledge.

Gilligan, C. (1992). In a different voice: Psychological theory and women's development. Cambridge, MA: Harvard University Press.

Graddol, P., \& Swann, J. (1989). Gender voices. Oxford, UK: Blackwell.

Gupta, S., \& Umar, A. (1994). Barriers to achievement faced by immigrant women of colour. In J. Gallivan, S.D. Crozier, and V.M. Lalande (Eds.), Women, girls, and achievement (pp. 56-62). North York, ON: Captus University Press.

Holmes, J. (1998). Women's talk: The question of sociolinguistic universals. In J. Coates (Ed.), Language and gender: A reader (pp. 461-483). Oxford, UK: Blackwell.

Hymes, D. (1972). Introduction. In C.B. Cazden, V.P. John, \& D. Hymes (Eds.), Functions of language in the classroom (pp. xi-xvii). New York: Teachers College Press.

Kramsch, C. (1993). Context and culture in language teaching. Oxford, UK: Oxford University Press.

Mahony, P. (1985). Schools for the boys? Co-education reassessed. London: Hutchinson.

Mahony, P. (1998). Girls will be girls and boys will be first. In D. Epstein, J. Ellwood, V. Hey, \& J. Maw (Eds.), Failing boys? Issues in gender and achievement (pp. 37-56). Milton Keynes, UK: Open University Press.

Orenstein, P. (1994). School girls: Young women, self-esteem, and the confidence gap. New York: Doubleday. 
Oxford, R. (1994). La différence ...: Gender differences in second/foreign language learning styles and strategies. In J. Sunderland (Ed.), Exploring gender: Questions and implications for English language education (pp. 140-147). New York: Prentice-Hall.

Oxford, R. (1993). Instructional implications of gender differences in a second/foreign . language (L2) learning styles and strategies. Applied Language Learning, 4, 142.

Sadker, M., \& Sadker, D. (1994). Failing at fairness: How America's schools cheat girls. New York: Scribner's.

Sheldon, A. (1997). Talking power: Girls, gender enculturation and discourse. In Wodak R. (Ed.), Gender and discourse (pp. 225-244). London: Sage.

Spender, D. (1980). Man made language. London: Routledge Kegan Paul.

Spender, D., \& Sarah, E. (Eds.). (1980). Learning to lose: Sexism and education. London: Women's Press.

Stanworth, M. (1981). Gender and schooling: A study of sexual divisions in the classroom. Explorations in Feminism No. 7. London: Women's Research and Resources Centre.

Statistics Canada. (1999). Government of Canada. Available: http://inforcan.gc.ca/facts

Stubbs, M. (1976). Language, schools and classrooms. London: Methuen.

Sunderland, J. (Ed.). (1994). Exploring gender: Questions and implications for English language education. New York: Prentice-Hall.

Sunderland, J. (1995). "We're boys, miss!": Finding gendered identities and looking for gendering of identities in the foreign language classroom. In S. Mills (Ed.), Language and gender: Interdisciplinary perspectives (pp. 160-178.). New York: Longman.

Sunderland, J. (1998). Girls being quiet: A problem for foreign language classrooms. Language Teaching Research, 2.

Swann, J., \& Stubbs, M. (1992). Girls, boys and language. Oxford, UK: Blackwell.

Thornborrow, J. (in press). Power talk. London: Longman.

Thorne, B. (1993). Gender play: Girls and boys in school. Milton Keynes, UK: Open University Press.

Vandrick, S. (1999a). Who's afraid of critical and feminist pedagogies? TESOL Matters, 9(1).

Vandrick, S. (1999b). The case for more research on female students in the ESL/EFL classroom. TESOL Matters, $9(2)$.

Walkerdine, V. (1990). Schoolgirl fictions. London: Verso.

Walkerdine, V. (1997). Daddy's girl: Young girls and popular culture. London: Macmillan.

West, C., \& Zimmerman, D.H. (1987). Doing gender. Gender and Society, 1, 125-151.

Willett, J. (1996). Research as gendered practice. TESOL Quarterly, 30, 344-347.

Yates, L. (1997). Gender, equity and the boys debate: What sort of challenge is it? British Journal of Sociology of Education, 18, 337-347.

Yepez, M. (1994). An observation of gender-specific teacher behavior in the ESL classroom. Sex Roles, 30, 121-133.

Zimmerman, D., \& West, C. (1975). Sex roles, interruptions and silences in conversation. In B. Thorne \& N. Henley (Eds.), Language and sex: Difference and dominance (pp. 105-129). MA: Newbury House. 